\title{
Colicins E4, E5, E6 and A and Properties of btuB+ Colicinogenic Transconjugants
}

\author{
By B. M. MALES AND B. A. D. STOCKER* \\ Department of Medical Microbiology, Stanford University School of Medicine, Stanford, \\ California 94305, U.S.A.
}

(Received 23 February 1981; revised 18 May 1981)

\begin{abstract}
E colicins are those inactive on btuB mutants, which lack the outer membrane protein that adsorbs vitamin B12, E colicins and phage BF23; types E1, E2, E3 and E7 have been defined by the specific immunity of E-colicinogenic strains to the type of $\mathrm{E}$ colicin they produce. Further immunity types - E4, E5 and E6 - are now described. Shigella sonnei of colicin type 9 makes colicin E4, and Shigella sonnei of types 9A, 12 and 14 make colicin E6 (not colicin E3, as previously supposed). Many local Shigella sonnei isolates make E colicin of a new type - E5. The action of colicins E1 to E7 was (incompletely) blocked by vitamin B12, which also reduced the effect of A colicins (which are weakly active on Escherichia coli $\mathrm{K} 12$ btuB indicators). Escherichia coli $\mathrm{K} 12$ given plasmid ColA-23 by transformation was immune to A colicins but sensitive to colicins E1 to E7. A purported 'colicin E4' was shown to be of class colicin A. Escherichia coli K12(CloDF 13) transformants were immune to colicin E6. A 'cap' of colicin-sensitive indicator bacteria developed over, but not around, killed colonies of $b t u B^{+}$E-colicinogenic strains, because of adsorption of colicin by non-induced bacteria of the colony. Killed colonies of $b t u B^{+}$E-colicinogenic strains gave partly discrete lobes of colicin action on indicator lawns, instead of circular zones, apparently as a result of unstable variation in colicin production. The presence of a colicin E4, E5 or E6 plasmid in $\mathrm{K} 12 \mathrm{btuB}^{+}$strains made them more sensitive to colicins E2 and E7, as shown by zones of partial translucency surrounding the ordinary colicin zones and by increased titre of colicin E2 and E7 preparations on such indicators.
\end{abstract}

\section{INTRODUCTION}

Colicins of group $\mathrm{E}$ are those which fail to act on colicin-resistant receptor-negative mutants, now assigned to class $b t u B$, and lacking an outer membrane protein which binds vitamin B12 and adsorbs both group E colicins and phage BF23 (Fredericq, 1949; DiMasi et al., 1973; Davies \& Reeves, 1975). Fredericq (1956) classified several E colicins into groups E1 and E2, defined by their inactivity on previously sensitive strains made, respectively, E1- or E2-colicinogenic by conjugation; colicins E1-K30 and E2-P9 (and the plasmids determining their production) are now taken as the types of the two groups. $\mathrm{E}$ colicins active on both E1-immune and E2-immune indicators were called group E3 (Fredericq, 1956). However, Inselburg (1974) showed that Escherichia coli K12 made E-colicinogenic by transfer of plasmid DNA from Fredericq's E3-producing strain CA38 was immune to this colicin but sensitive to E1 and E2 colicins, and so defined an E3-CA38 immunity group. [We hereinafter use E3 to indicate the colicin, and plasmid, of the CA38 kind, rather than in the wider sense of Fredericq (1956).] We reported (Males \& Stocker, 1980) that the E colicin made by strain CL137 (a K12 derivative), and by Fredericq's strain K317 
from which it derived colicinogeny, is not an E2 colicin (as formerly supposed) but of a previously undescribed immunity type, which we termed E7. We now describe three further types of E colicin - E4, E5 and E6. One of them was first recognized by Horak (1975) and labelled by him E4. This symbol had been previously used for the colicin made by an E. coli strain which is no longer available (Hamon \& Peron, 1964; Y. Hamon, personal communication) and was recently used (Cavard \& Lazdunski, 1979) to describe a bacteriocin since shown to be of type A (this paper; C. Lazdunski, personal communication). However, we follow Horak (1975) and use symbol E4 for colicin E of the kind made by Shigella sonnei of colicin type 9. Horak (1975) also reported that $S$. sonnei of colicin types $9 A, 12$ and 14 produced $\mathrm{E}$ colicins of a kind which he called colicin E3; we find this $\mathrm{E}$ colicin differs from colicin E3 as defined above and we therefore, in agreement with Dr V. Horak (personal communication), now call it colicin E6. Many $S$. sonnei strains from amongst a set recently isolated in San Francisco produced an E colicin of a further new type, which we call E5. Colicin $\mathrm{A}$ is related to the $\mathrm{E}$ colicins in that $b t u B$ mutants of $E$. coli $\mathrm{K} 12$ show greatly reduced sensitivity to colicin A and in that the presence of vitamin B12 blocks the activity of colicin A, as well as those of E colicins (this paper; Van Vught \& Delamarre, 1977; Kadner et al., 1979). We therefore included available strains producing colicin A in our investigation.

We had occasion to transfer colicinogeny to btu $B^{+} E$. coli $\mathrm{K} 12$ recipient strains by conjugation or, in some instances, by application of plasmid DNA to competent cell suspensions. In our examination of the resulting E-colicinogenic btuB $B^{+}$transconjugants or transformants we encountered some unexpected phenomena: the production of double zones by action of some $\mathrm{E}$ colicins on some non-immune E-colicinogenic indicator strains; the growth of colicin-sensitive indicator bacteria immediately over chloroform-killed macrocolonies of $b t u B^{+}$E-colicinogenic strains but not around them; and irregular zones of colicin action, perhaps resulting from heterogeneity of colicin production within colonies of some colicinogenic strains.

\section{METHODS}

Media. The media and conditions of incubation used were as before (Males \& Stocker, 1980).

Bacterial strains and phages. The principal strains used are listed in Tables 1 and 2 . Mutants resistant to all $\mathrm{E}$ colicins and to phage BF23, presumed to be $b t u B$, were selected in $b t u B^{+}$E-colicinogenic strains by picking from colonies appearing within a zone of $E$ colicin action, followed by single-colony re-isolation and tests of sensitivity to colicins EI to E7 and to phage BF23. Phage BF23 was used to test the btuB character of E. coli and $S$. sonnei strains.

Colicin and genetic methods. Production of, and sensitivity to group E colicins, colicin A and other colicins were tested as before (Males \& Stocker, 1980). For tests of the sensitivity of an indicator strain to the E colicin made by a strain which produced also an Ia or Ib colicin, we isolated mutants of the indicator strain resistant to colicins Ia and $\mathrm{Ib}$ (commonly also resistant to colicins $\mathrm{B}, \mathrm{M}$ and $\mathrm{V}$, probably of class ton $B$ ). Colicinogenic strains were tested for their ability to transmit colicinogeny (or colicin-immunity without colicinogeny) by conjugation, as previously described (Males \& Stocker, 1980); if no colicinogenic (or colicin-immune) transconjugants were found by testing recipient-type colonies selected as streptomycin-resistant or nalidixate-resistant, transconjugants with an antibiotic resistance trait of the donor were selected, and tested for colicin production and immunity. Cell-free colicin preparations (filtrates from untreated broth cultures or cultures exposed to mitomycin $\mathrm{C}$ ) were titrated for colicin activity on seeded soft-agar layers with or without vitamin B12 at various concentrations, as before (Males \& Stocker, 1980).

An $\mathrm{F}^{\prime}$ factor carrying gene $b t u B^{+}$and a dominant rifampicin-resistance allele (Kirschbaum \& Konrad, 1973) was transferred from an auxotrophic donor strain, E109a (Table 1), into several btuB recipient strains by conjugation and selection on defined medium with rifampicin $\left(12.5 \mu \mathrm{g} \mathrm{ml}^{-1}\right)$.

To transfer colicinogeny by transformation, plasmid DNA fractions from cleared lysates of colicinogenic strains were mixed, in about equal parts, with plasmid pSC101 DNA; the DNA mixture was used, at saturating concentration, to transform competent cells of $E$. coli K12 strain JA194 to tetracycline-resistance. Tetracyclineresistant clones found to produce colicin were tested to determine the range of activity of their colicin(s) and for colicin immunities. 
Table 1. Non-colicinogenic strains and strains producing colicins E1, E2, E3, E7 or A

Strain no.

Description*

Used as

Source/Reference

Non-colicinogenic strains

$\mathrm{CL} 142 \dagger$

Escherichia coli $\mathrm{K} 12-\mathrm{Row}$, rpsL

(ג) $\mathrm{F}^{-}$

023BM Mutant of CL142 resistant to

E colicins and phage BF23, presumed btuB

CL279 Streptomycin-resistant derivative of

$E$. coli K12 W1895 Hfr $1(\lambda)$

JA194 E. coli K 12 C600 restriction-negative

AG037

AG041

E. coli $\mathrm{B}$

$\operatorname{trp}(\operatorname{ton} B)_{\Delta}$ mutant of $E . \operatorname{coli} \mathrm{B}$

P555

tol mutant in an E. coli $\mathrm{K} 12$ line

CL18

E109a

$E$. coli $\phi$ of Gratia

E. coli $\mathrm{K} 12$ metB argG his leu recA (F'rif)
Indicator for all $\mathrm{E}$ colicins, colicin A and BF23; conjugational recipient

E-resistant indicator

Conjugational recipient

Recipient for

transformation

Indicator for E colicins

Indicator for $\mathrm{E}$ colicins

but resistant to I colicins

Indicator tolerant to $\mathrm{E}$ and A colicins

Indicator for all colicins

Donor of $\mathrm{F}^{\prime}$ carrying $b t u B^{+}$ and dominant rifampicinresistance allele
Ozeki et al. (1962);

Males \& Stocker (1980)

Males \& Stocker (1980)

Males \& Stocker (1980)

A. Chang

S. Guterman

Graham (1974)

Davies \& Reeves (1975)

Ozeki et al. (1962)

Kirschbaum \& Konrad

(1973)

Colicinogenic strains reported as producing colicins E1, E2, E3-CA38, E7-K317 (or combinations of these) or $\operatorname{colicin} A$

\begin{tabular}{|c|c|}
\hline CL136 & $\begin{array}{l}\text { E. coli } \mathrm{K} 12 \text { line } 112-12 \ddagger \text { carrying } \\
\text { ColE } 1-\mathrm{K} 30\end{array}$ \\
\hline 189BM & $\begin{array}{l}\text { E. coli } \mathrm{K} 12 \text { line } \mathrm{P} 678-54 \S \text { given } \\
\text { ColE2-P9 by transformation }\end{array}$ \\
\hline 190BM & $\begin{array}{l}\text { E. coli } \mathrm{K} 12 \text { line } \mathrm{P} 678-54 \S \text { given } \\
\text { ColE } 3-\mathrm{CA} 38 \text { by transformation }\end{array}$ \\
\hline 245BM & $\begin{array}{l}\text { E. coli } \mathrm{K} 12 \text { line } 112-12 \ddagger \text { carrying } \\
\text { ColE } 7-\mathrm{K} 317\end{array}$ \\
\hline CL137 & $\begin{array}{l}\text { E. coli K } 12 \text { line } 112-12 \ddagger \text { carrying } \\
\text { ColE } 7-\mathrm{K} 317 \text { and ColE } 2 \text { imm-K } 317\end{array}$ \\
\hline 094BM & $\begin{array}{l}\text { E. coli } \mathrm{K} 12 \text { line } \mathrm{P} 678-54 \S \text { given } \\
\text { ColE1-K } 30 \text {, ColE2-P9 and ColE3- } \\
\text { CA } 38 \text { by transformation }\end{array}$ \\
\hline CA31 & $\begin{array}{l}\text { Citrobacter freundii producing } \\
\text { colicin A; resistant to E colicins and } \\
\text { phage BF } 23\end{array}$ \\
\hline 23 (Barry) & $\begin{array}{l}\text { E. coli producing colicin } A \text {; resistant } \\
\text { to E colicins and phage BF } 23\end{array}$ \\
\hline $20-78$ & $\begin{array}{l}\text { Citrobacter sp. producing a colicin; } \\
\text { resistant to E colicins and phage } \\
\text { BF } 23\end{array}$ \\
\hline N3675 & $\begin{array}{l}\text { E. coli } \mathrm{K} 12 \text { line carrying cloacin } \\
\text { plasmid CloDF } 13\end{array}$ \\
\hline
\end{tabular}

Producer of colicin E1, indicator immune to E1

Producer of colicin E2, indicator immune to $\mathrm{E} 2$

Producer of colicin E3, indicator immune to E3

Producer of colicin E7, indicator immune to E7

Producer of colicin E7, indicator immune to $\mathrm{E} 2$ and E7

Producer of colicins E1, $\mathrm{E} 2$ and E3, indicator immune to E1, E2 and E3

Producer of colicin A

Producer of colicin A; source of plasmid DNA Producer of colicin 'E4', now identified as colicin A

Found immune to colicin E6
Lewis \& Stocker (1965);

Males \& Stocker (1980)

Inselburg (1974);

Males \& Stocker (1980)

Inselburg (1974);

Males \& Stocker (1980)

Males \& Stocker (1980)

Lewis \& Stocker (1965);

Males \& Stocker (1980)

Inselburg (1974)

Fredericq (1965)

Barry et al. (1963)

Cavard \& Lazdunski (1979)

Kool et al. (1975)

* Only relevant nutritional and mutant characters are listed.

† Strain CL142, of Ozeki et al. (1959) and Lewis \& Stocker (1965), is identical to Fredericq's strain K 12-Row, 58-161, metB1, rpsL $(\lambda), \mathrm{F}^{-}$or with defective F (P. Fredericq, personal communication).

¥ Strain 112-12 (parent of CL136 and CL137) is $\mathrm{K} 12 \mathrm{~F}^{+} \lambda^{-}$gal his cys rpsL (P. Fredericq, personal communication).

$\S$ Strain P678-54, from which Inselburg (1974) derived these E-colicinogenic transformants, is $\mathrm{K} 12 \mathrm{~F}^{-}$ gal lac thr leu min rpsL. 
Table 2. Strains producing $E$ colicins other than E1,E2, E3 or E7, or previously not identified combinations of E colicins

\begin{tabular}{|c|c|c|}
\hline Strain no. & Description* & Source/Reference \\
\hline 305BM & Shigella sonnei, colicin type $9 ;$ produces colicins E4 and Ia & Horak (1975) \\
\hline K365 & $\begin{array}{l}\text { Escherichia coli producing an E colicin now identified as } \\
\text { colicin E4 }\end{array}$ & P. Fredericq (pers. comm.) \\
\hline K384 & E. coli producing an E colicin now identified as colicin E4 & P. Fredericq (pers. comm.) \\
\hline 304BM & $\begin{array}{l}\text { S. sonnei, indicator } 8 \text { in colicin typing scheme (Abbott \& } \\
\text { Shannon, 1958); produces colicin E6 }\end{array}$ & Horak (1975) \\
\hline 306BM & $\begin{array}{l}\text { S. sonnei, colicin type 9A (Horak, 1975); produces colicins E6 } \\
\text { and Ia }\end{array}$ & Horak (1975) \\
\hline 307BM & $\begin{array}{l}\text { S. sonnei, colicin type } 12 \text { (Abbott \& Shannon, 1958); produces } \\
\text { colicin E6 }\end{array}$ & Horak (1975) \\
\hline 308BM & $\begin{array}{l}\text { S. sonnei, colicin type } 14 \text { (Abbott \& Shannon, 1958); produces } \\
\text { colicins E6 and Ib }\end{array}$ & Horak (1975) \\
\hline 099BM & S. sonnei; $\mathrm{Tc}, \mathrm{Su}, \mathrm{Sm}$; produces colicins E5 & Local isolate ${ }^{\dagger}$ \\
\hline 101BM & $\begin{array}{l}\text { S. sonnei; } \mathrm{Tc}, \mathrm{Su}, \mathrm{Sm} \text {; produces colicins } \mathrm{E} 2 \text { and } \mathrm{E} 5 \text { and is } \\
\text { immune to them and to colicins } \mathrm{E} 1 \text { and } \mathrm{E} 7\end{array}$ & Local isolate \\
\hline 104BM & $\begin{array}{l}\text { S. sonnei; } \mathrm{Tc}, \mathrm{Su}, \mathrm{Sm} ; \text { produces colicin } \mathrm{E} 5 \text { and is immune to it } \\
\text { and to colicins } \mathrm{E} 1 \text { and } \mathrm{E} 7\end{array}$ & Local isolate \\
\hline P33 (Vosti) & $\begin{array}{l}\text { E. coli producing colicin(s) previously identified as of group } \mathrm{E} \text {, } \\
\text { now shown to be colicins } \mathrm{E} 1 \text { and } \mathrm{E} 4\end{array}$ & Vosti (1968) \\
\hline
\end{tabular}

\section{RESULTS}

\section{Incidence of strains producing $E$ colicins of different types}

Testing of many Escherichia coli and Shigella sonnei strains and a few strains of other species, either reported to produce $\mathrm{E}$ colicins or not previously examined, confirmed production of colicin E1, E2, E3 or E7 by several strains, and yielded 31 E1-producing and 3 E2-producing strains from amongst those not previously tested. No strains producing colicin E3 or colicin E7 other than the 'type' strains were detected. Strains provided by Dr V. Horak fell into two groups, each making a distinctive E colicin, as reported by him (Horak, 1975). Tests on S. sonnei strains recently isolated in San Francisco showed many of them to produce an $E$ colicin of a further new type. We consider below each of the three types of $E$ colicin thus revealed.

\section{Colicin H $_{\text {Horak }}$}

Horak (1975) reported that the type $S$. sonnei strain for colicin type 9 in the typing scheme of Abbott \& Shannon (1958) produced an Ia colicin and an E colicin which he called E4. Our results (Table 3 ) confirmed that this strain (labelled by us 305BM) produces colicin Ia and an $\mathrm{E}$ colicin active on indicators resistant or immune to colicin Ia and immune to colicin $\mathrm{E} 1$, $\mathrm{E} 2$, E3-CA38 or E7, and also active on $094 \mathrm{BM}$, an E. coli $\mathrm{K} 12$ derivative carrying three colicin E plasmids, ColE1-K30, ColE2-P9 and ColE3-CA38 (Inselburg, 1974). The E4-colicinogenic strain, 305BM, was sensitive to phage BF23 and to colicins E1, E2-P9, E3-CA38 and E7-K317 but not to its own E colicin (or colicin Ia-CA53). We follow Horak by indicating the new immunity type as $\mathrm{E} 4$ (or as $\mathrm{E} 4_{\mathrm{Horak}}$, to emphasize the distinction from E4 used in other senses, noted above). The E4-colicinogenic strain, 305BM, as expected (because of its production of colicin Ia, always determined by a conjugative plasmid), transmitted colicinogeny to a $\mathrm{K} 12$ recipient strain. All of 25 colicinogenic transconjugants showed the colicinogenic activities and immunities expected from acquisition of both the Colla and the ColE4 plasmid of the donor strain. We recently received from Dr P. Fredericq 
Table 3. Action of E colicins, colicin A and phage BF23 on E. coli K12 lines carrying colicin plasmids or resistant or tolerant by mutation

\begin{tabular}{|c|c|c|c|c|c|c|c|c|c|c|c|}
\hline \multirow{2}{*}{$\begin{array}{l}\text { Plasmid(s) } \\
\text { carried or } \\
\text { mutation }\end{array}$} & \multirow[b]{2}{*}{$\begin{array}{l}\text { Representative } \\
\text { strain }\end{array}$} & \multicolumn{9}{|c|}{ Colicin } & \multirow[b]{2}{*}{$\begin{array}{l}\text { Phage } \\
\text { BF 23 }\end{array}$} \\
\hline & & E1 & E2 & E3 & $\mathrm{E} 4 \dagger$ & E5 & E6 & E7 & A & $\mathrm{EI}+\mathrm{E} 4 \ddagger$ & \\
\hline (none) & CLl42 & + & + & + & + & + & + & + & + & + & + \\
\hline ColE 1-K30 & CL136§ & - & + & + & + & + & + & + & + & + & + \\
\hline ColE2-P9 & $189 \mathrm{BM} \|$ & + & - & + & + & + & + & + & + & + & + \\
\hline ColE3-CA38 & 190BM $\|$ & + & + & - & + & + & + & + & + & + & + \\
\hline ColE4-CT9 & $316 \mathrm{BM} \S$ & + &,$+ \mathrm{D}$ & + & - & + & + &,$+ \mathrm{D}$ & + & + & + \\
\hline ColE5-099 & 198BM§ & + &,$+ D$ & + & + & - & + &,$+ \mathrm{D}$ & + & + & + \\
\hline ColE6-CT 14 & $318 \mathrm{BM} \S$ & + &,$+ \mathrm{D}$ & + & + & + & - &,$+ D$ & + & + & + \\
\hline ColE 7-K317 & $245 \mathrm{BM} \S$ & + & + & + & + & + & + & - & + & + & + \\
\hline CloDF 13 & N3675॥ & + & + & + & + & + & - & + & + & + & + \\
\hline $\begin{array}{l}\text { ColE1-P33 and } \\
\text { ColE4-P33 }\end{array}$ & 365BM§ & - & + & + & - & + & + & + & + & - & + \\
\hline ColA-23 & $367 \mathrm{BM} \|$ & + & + & + & + & + & + & + & - & + & + \\
\hline$b t u B$ & 023BM & - & - & - & - & - & - & - & \pm & - & - \\
\hline tol & P555 & \pm & \pm & \pm & \pm & \pm & \pm & \pm & \pm & NT & + \\
\hline
\end{tabular}

+ , Indicator strain fully sensitive to colicin (wide zone) or phage;,$+ \mathrm{D}$, colicin produces clear inner zone and outer zone of partial translucency; \pm , weak colicin action, zone much narrower than on control fully sensitive strain; -, no or very slight colicin action (no zone, or very narrow, turbid zone), or no phage action; NT, not tested.

* In the case of colicins made by strains that also produce an I colicin, the reactions shown are those of a mutant of the indicator selected as resistant to colicin I.

$\uparrow$ Colicin $\mathrm{E}_{\text {Horak }}$.

$\mp$ Colicin(s) made by strain P33, inferred to be colicins E1 and E4.

$\S$ E-colicinogenic transconjugant.

II Colicinogenic or bacteriocinogenic transformant.

two $E$. coli strains, $\mathrm{K} 365$ and $\mathrm{K} 384$, noted by him to produce $\mathrm{E}$ colicin(s) active on indicators immune to colicins E1, E2, E3 or E7. We found both strains produced E colicin inactive on our E4-immune indicator, $316 \mathrm{BM}$ (which is $E$. coli $\mathrm{K} 12$ line CL142 made E4-colicinogenic and Ia-colicinogenic by growth with 305BM, the $S$. sonnei colicin type 9 strain). Strain K384 was not affected by any E colicin or by phage BF23 and is, presumably, btuB: strain K365 was sensitive to phage BF23 and to colicins E1, E2, E3 and E7 but not to colicin E4. We infer that both strains produce colicin E4.

\section{Colicin E6}

Horak (1975) reported production of what he called colicin E3 by strains of three of the types in the $S$. sonnei colicin typing scheme: type 9A, producing also colicin Ia; type 12 , producing only the E colicin; and type 14, producing also colicin Ib. The $S$. sonnei strain used as indicator 8 in his extension of the typing scheme also produced the same type of $E$ colicin. We found each of these four strains to produce an E colicin active on indicators immune to colicin E1, E2-P9, E4 or E7-K317 but inactive on all four of this set of producing strains (Table 3). (We also confirmed Horak's identification of colicin Ia or Ib produced by two of the strains.) However, we found the $\mathrm{E}$ colicins of these four strains active on $\mathrm{K} 12$ derivatives carrying ColE3-CA38, and that all four strains were sensitive to colicin E3-CA38 (and also to colicins E1, E2, E4 and E7). Thus these four E colicins fall in a single immunity group but this group is distinct from that defined by colicin E3-CA38. In agreement with Horak (personal communication) we propose that this type of colicin be termed E6. Horak's colicin type 14 strain, our $308 \mathrm{BM}$, was tested as a donor; all of 25 colonies of the $\mathrm{K} 12$ recipient, re-isolated on streptomycin nutrient agar after overnight mixed culture, were colicinogenic, with colicin activities and immunities indicating acquisition of both the $\mathrm{Ib}$ and the E6 
colicinogeny of the donor. We have not so far encountered any other strains producing E6 colicin.

\section{Colicin E5}

Test of $30 S$. sonnei isolates from San Francisco General Hospital showed that 14 of them produced (only) E colicin (or E colicins) active on singly colicinogenic K12 indicator strains immune to colicins E1, E2, E3-CA38, E4, E6 or E7. The E colicin(s) produced by 13 of the 14 isolates were inactive, or only very weakly active, on the 9 members of the set of 14 which were $b_{t u B^{+}}$(as shown by sensitivity to phage BF23) and were inactive also on K12 transconjugants deriving $E$ colicinogeny from some of the 14 isolates. This showed that all 13 strains made an $\mathrm{E}$ colicin of a not previously observed immunity type, which we call type E5. (Strain 101BM, the one member of the set of 14 producing E colicin active on indicators immune only to colicin E5, was shown, as described below, to produce colicin E2 in addition to colicin E5.) Five of the 14 E5-producing $S$. sonnei isolates failed to transmit colicinogeny to two K12 recipients (and the four which were resistant to one or more antibacterial agents were likewise unable to transmit any such resistance to K12). Nine E5-producing S. sonnei strains transmitted colicinogeny to one or both of the $\mathrm{K} 12$ recipients used; in most crosses colicinogeny was observed only amongst transconjugants selected for acquisition of a donor resistance (to ampicillin, tetracycline or sulphonamides). The $\mathrm{K} 12$ (ColE5) transconjugants tested showed the expected immunity to colicin E5. However, macrocolonies of strains producing much colicin E5 were surrounded by narrow, usually turbid, zones of colicin action on $\mathrm{K} 12 b_{t u B^{+}} \mathrm{E} 5$-colicinogenic transconjugants; it seemed that the immunity of colicinogenic strains to colicin of the type they produce is less nearly complete for colicin E5 than for other E colicins.

Several E5-producing $S$. sonnei isolates able to transfer colicinogeny showed more than one E colicin property. Three strains producing only colicin E5 were immune to colicin E1 as well as to E5; all three strains transmitted E5 colicinogeny to $\mathrm{K} 12$; the E5-colicinogenic transconjugants from one cross were immune to colicin E1. Isolate 104BM produced only colicin E5 and was immune to colicins E5, E1 and E7. K12 transconjugants showed 5 of the 7 possible combinations of three donor colicin characters. Isolate $101 \mathrm{BM}$ produced colicins E5 and E2 and was immune to these and to colicins E1 and E7. Transconjugants showed 10 of the 15 possible combinations of the four donor colicin properties. We infer transfer of plasmids determining colicin immunity but not production, like plasmid ColE2imm-K317 of E. coli K317 (Males \& Stocker, 1980).

\section{E colicins made by strain P33}

Escherichia coli strain P33 (Vosti, 1968) made colicin(s) inactive on btuB indicators but active on all available immune indicators, including one immune to E1, E2, E5 and E7 and another immune to E1, E2 and E3. Strain P33 did not transfer colicinogeny during mixed growth with a $\mathrm{K} 12$ strain and was resistant to all E colicins and phage BF23; an attempt to introduce the $\mathrm{F}^{\prime}$ btuB $B^{+}$rif factor failed. To test whether strain P33 made a new kind of $\mathrm{E}$ colicin or two (or more) E colicins, plasmid DNA from this strain mixed with pSC101 DNA was used to transform a $\mathrm{K} 12$ recipient to tetracycline-resistance. Of 416 transformants tested 92 were colicinogenic: 71 made, and were immune only to, colicin E1; 12 made, and were immune only to, colicin E4; and 9 were immune to both E1 and E4 and made colicin(s) active on all singly immune E-colicinogenic indicators. Thus strain P33 makes colicins E1 and E4.

\section{Colicin A, and a purported colicin E4}

Two strains known to produce colicin A, Citrobacter freundii strain CA31 of Fredericq (1965) and E. coli strain 23 of Barry et al. (1963), made colicin fully active on all E-immune indicators and weakly active (narrow zones) on btuB mutants of $E$. coli $\mathrm{K} 12$. Both strains were resistant to all E colicins and phage BF23, and so presumably were $b t u B$, and neither 
transmitted colicinogeny during mixed culture. Plasmid DNA from strain 23 mixed with plasmid pSC101 DNA transformed a $b t u B^{+} \mathrm{K} 12$ recipient to tetracycline-resistance. Of 454 transformants 84 were colicinogenic, producing a colicin identified as colicin A, and weakly active on a $b t u B$ indicator; the width of the zones obtained with a $b t u B^{+}$indicator varied considerably between transformants. The colicinogenic transformants were sensitive to colicins E1 to E7 but immune to colicin A, made by strain CA31 or strain 23.

Citrobacter strain 20-78 makes a colicin for which the symbol E4 was proposed (Cavard $\&$ Lazdunski, 1979). We found this colicin weakly active on $b t u B$ indicators; these indicators were also somewhat sensitive to colicins A-CA31 and A-23. The 20-78 colicin was inactive on our A-colicinogenic transformants, carrying the colicin A plasmid from strain 23; these transformants were sensitive to colicins E1 to E7. An antiserum against the 20-78 colicin (provided by Drs D. Cavard \& C. J. Lazdunski), applied undiluted to chloroform-killed stab-inoculated colonies before addition of a soft-agar layer, neutralized the colicin activity of strains CA31 and 23 (which make colicin A) as well as that of strain 20-78, but did not neutralize any of colicins E1 to E7. Thus the colicin made by strain 20-78 is of type A.

\section{Immunity conferred by bacteriocin plasmid CloDF13}

Cloacin DF13 does not act on E. coli (Kool et al., 1975). Though this bacteriocin kills by the same mechanism as colicin E3-CA38, the plasmid determining its production, transferred to an $E$. coli $\mathrm{K} 12$ line by DNA-mediated transformation, gave little if any immunity to colicin E3-CA38 (Kool et al., 1975). Several K12(CloDF 13) transformant clones (received from Drs B. Oudega \& E. Veltkamp) were sensitive to phage BF23, colicin A and colicins E1, E2, E3, E4, E5 and E7 but unaffected by colicin E6 (produced by four strains of independent origin); these latter, however, were active on the K12 strain not given the cloacin plasmid.

\section{Blocking of action of colicins of type $E$ and of colicin $A$ by vitamin B12}

Macrocolonies of btuB strains producing colicins E4, E5 or E6 gave zones on various $b t u B^{+}$non-immune $E$. coli indicator strains which resembled those produced by colicins $\mathrm{E} 1$, E2, E3 or E7: that is, they were several millimetres wide, sharp-edged and clear, with some resistant colonies (very few for most indicators, but very many when the indicator was CL142). The presence of vitamin B12 in the inoculated soft-agar layer abolished the zones or reduced their width. The presence of the vitamin in a soft-agar layer also reduced the titres (last dilution to cause definite clearing) of cell-free colicin preparations (supernatants either of untreated broth cultures or of cultures exposed to mitomycin $C$, which had titres usually 10 to $10^{4}$ times higher than control preparations). Vitamin B12 at $10 \mu \mathrm{M}$ caused a reduction in titre by factors of 0.1 to 0.001 . Somewhat greater reductions were usually observed with the vitamin at $100 \mu \mathrm{M}$ or $1 \mathrm{mM}$ but even then some colicin activity was visible. The vitamin at $1 \mu \mathrm{M}$ had no obvious effect. The blocking effect of vitamin B12 was observed to about the same extent for each of the E colicins, E1 to E7; blocking was also seen for colicin A made by two different strains. Vitamin B12 had no effect on the titres of preparations of colicins $B, D$, $\mathrm{Ia}, \mathrm{Ib}, \mathrm{K}$ or $\mathrm{V}$.

\section{E-colicinogenic btuB ${ }^{+} \mathrm{K} 12$ transconjugants as colicin-producers: capping and lobate-edge clearings}

Chloroform-killed macrocolonies of $b t u B^{+}$E-colicinogenic strains (obtained by conjugal transfer of $\mathrm{E}$ colicin plasmids to $E$. coli $\mathrm{K} 12$ lines) produced only narrow zones of colicin clearing, even on $E$. coli strains $\phi$ and B, which we found to be more sensitive to E colicins than strain K12. Two anomalous appearances were noted in such tests of colicin action. Often the surface of the soft-agar immediately over all or part of a macrocolony was matt or granular, instead of smooth and shiny as it was over the clear zones of colicin action around the macrocolony. Subculture from such matt areas gave abundant growth of the indicator strain, which on retest was still colicin-sensitive. This appearance somewhat resembled the 


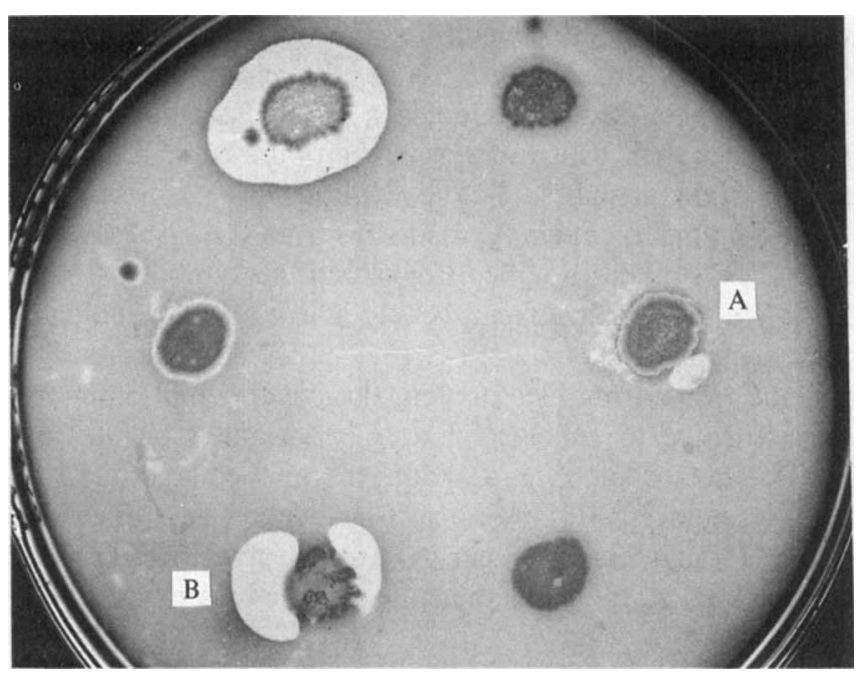

Fig. 1. 'Lobate-edge' colicin zones and 'capping' over macrocolonies of some $b t u B^{+}$E-colicinogenic transconjugant strains. The indicator is AG041, a tonB $B_{\Delta}$ mutant of $E$. coli B. Colonies A and B, showing lobate-edge colicin zones, are, respectively, strain 198BM, a K 12 subline given ColE5-099, and strain 263BM, a K12 subline given ColE5-104 and ColE1 imm-104. An incomplete 'cap' of growth of indicator can be seen over macrocolony $\mathrm{B}$.

'cap' of growth of colicin-sensitive indicator bacteria developing above the streak of growth of a colicin-tolerant strain (able to adsorb colicin but not killed by it) on colicin-containing agar, described by Hill \& Holland (1967). We therefore use their term 'cap' to describe the colicin-sensitive bacterial growth immediately over, but not around, killed $b t u B^{+} \mathrm{E}$ colicinogenic macrocolonies. If the macrocolony tested was a $b t u B$ mutant, instead of $b t u B^{+}$, no cap was seen, and the zone of colicin clearing was wider. Vitamin B12 (10 $\mu \mathrm{M})$ in the bottom nutrient-agar layer only (i.e. presence of the vitamin during growth of the colicin-producing $b t u B^{+}$macrocolony) eliminated capping; it also somewhat reduced the width of zones, presumably because of diffusion of vitamin into the soft-agar layer. Though no caps were seen over macrocolonies of various btuB E-colicinogenic transconjugants, typical caps developed over macrocolonies grown from inocula containing a minority (about $0.1 \%$ ) of cells of such a $b t u B$ E-colicinogenic strain added to a culture of the (incompletely) E-tolerant K12 mutant P555 (Davies \& Reeves, 1975), able to adsorb E colicins but not killed by them.

When capping was present the appearance we call 'lobate edge' was often seen. Instead of a narrow, uniform-width zone of clearing round the macrocolony, there were partly discrete lobes of clearing, extending outwards from different points at or near the periphery of the macrocolony, as though colicin was present at high concentration at only a few sites within or over the macrocolony (Fig. 1). The lobate-edge appearance was noted for many transconjugants producing colicin E5, for some producing E7 and, on a few occasions, for E1-producing transconjugants. Use of $b t u B$ mutants as producers, or the presence of vitamin $\mathrm{B} 12(10 \mu \mathrm{M})$ in the bottom agar layer (i.e. during growth of the colicinogenic strain) resulted in wide, uniform-edge zones of colicin activity, i.e. eliminated the lobate-edge appearance as well as eliminating capping. However, lobate edge (as well as capping) was obtained when the inoculum for a macrocolony was a mixture (as described above) of a majority of colicin-tolerant, non-colicinogenic $b t u B^{+}$bacteria and a minority of cells of a $b t u B$ derivative of a colicinogenic transconjugant.

The lobate-edge appearance suggested heterogeneity of colicin production of the population making up macrocolonies of $b t u B^{+}$E-colicinogenic strains. All of many single-colony re-isolates of such strains were colicinogenic and immune to their own type of colicin but 


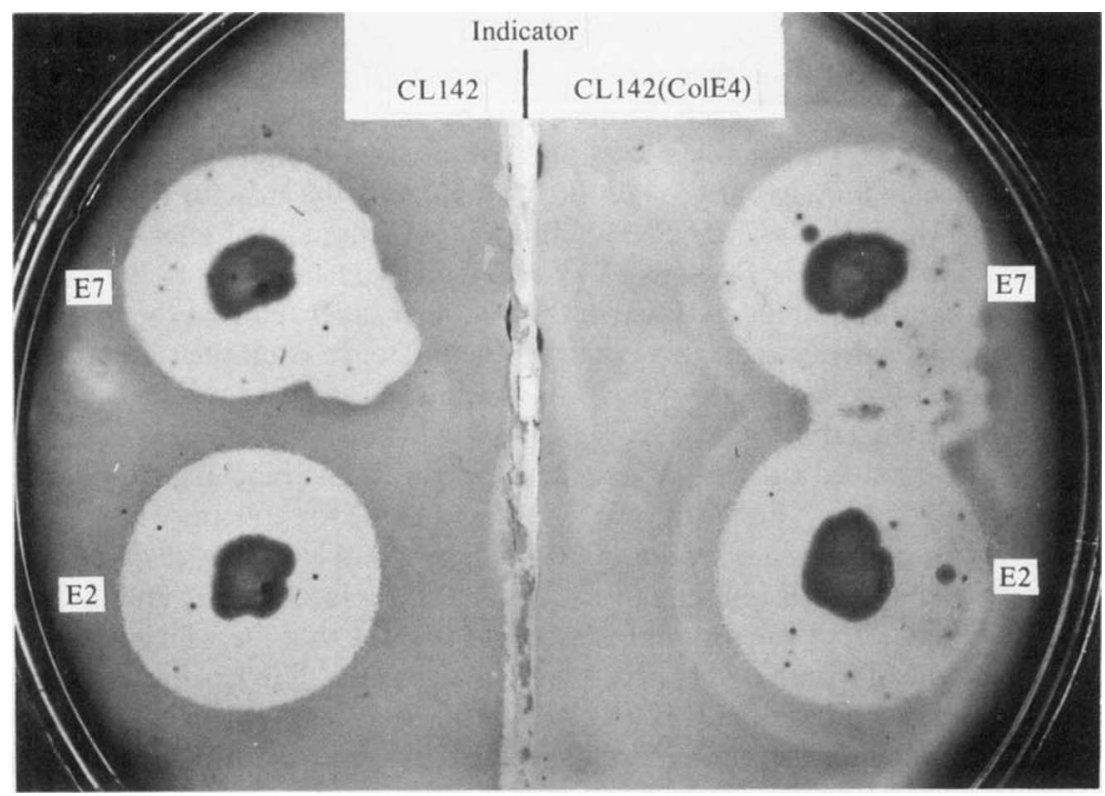

Fig. 2. Double-zone phenomenon. The upper two macrocolonies are Salmonella typhimurium SL906, producing colicin E7-K317; the lower two are Salmonella typhimurium SL907, producing colicin E2-P9. The indicator on the left is E. coli CL142 (not carrying any colicin plasmid); that on right is CL142 carrying ColE4-CT9 and Colla-CT9.

sensitive to phage BF23 and heterologous E colicins, so the inferred heterogeneity cannot consist of loss of the $\mathrm{E}$ colicin plasmid by most of the bacteria in the population making up a macrocolony. However, in one experiment we detected evidence for unstable variation amongst sister colonies in the amount of colicin released (data not shown); we have not further investigated this question.

\section{Double zones of colicin E2 or E7 action on some E-colicinogenic indicators}

When $b t u B^{+}$strains carrying a single E colicin plasmid, either ColE4-CT9 or ColE6-CT14 or any of several ColE5 plasmids, were used as indicators for detection of colicin E2 or colicin E7, double zones were usually seen. An inner zone of about the width and clearness typical of $\mathrm{E}$ colicin zones was surrounded by an outer zone, several millimetres wide, of partial translucency (Fig. 2). No zones were produced if the E4- or E5- or E6-colicinogenic indicator strain was made $b t u B$. Cell-free preparations of colicin E2 or E7 added to wells cut in a soft-agar layer plate produced the same double-zone effect as chloroform-treated macrocolonies of an E2- or E7-colicinogenic strain. The outer and inner zones surrounding an E2-producing macrocolony fused with the corresponding zones round an adjacent E7-producing macrocolony (Fig. 2), as though each of the two kinds of colicin produced an outer zone by the same mechanism. The width of the outer and inner zones combined was greater than the width of the single zones produced on isogenic non-colicinogenic indicators (Fig. 2); this suggested that $b t u B^{+} \mathrm{K} 12$ carrying colicin E4 or E5 or E6 plasmids were more sensitive to colicins E2 and E7 than were non-colicinogenic related strains. This surmise was tested by titration of cell-free preparations of colicins E2 and E7; their titres were found to be 3 to 100 times higher on representative E4-, E5- and E6-colicinogenic indicators than on their non-colicinogenic parent strains. Several transconjugant lines carrying both an E5 colicin factor and one (or two) plasmids of class ColE2 or ColE1 imm or ColE7imm did not show double zones when used as indicators for colicins E2 or E7; the titres of cell-free preparations of these two colicins were 0.1 to 0.01 times lower on these transconjugant lines than on isogenic non-colicinogenic strains. 


\section{DIS CUSSION}

Our present results and two earlier reports (Horak, 1975; Males \& Stocker, 1980) show there are seven kinds of $\mathrm{E}$ colicin, each distinguished by a specific colicinogenic immunity. The $\mathrm{E}$ colicins are defined by their inactivity on a class of resistant mutant, resistant also to phage BF23, now known to be mutated at gene $b t u B$ (formerly $b f e$ ), the structural gene for the outer membrane protein which binds vitamin B12. Inhibition of the killing effect by vitamin B12 has been noted for colicins E1, E2 and E3 (Van Vught \& Delamarre, 1977; Kadner et al., 1979). We found that the vitamin at $10 \mu \mathrm{M}$ in the soft-agar layer reduced the titres of colicins E1 to E7 to about the same extent; this confirms the inference from their inactivity on btuB mutants that all seven E colicins adsorb to a site which is the same as, or at least overlaps, the site of adsorption of the vitamin.

Vitamin B12 also reduced the titre of colicin A preparations; blocking of killing effect by this vitamin was reported by Van Vught \& Delamarre (1977) for colicin A and by Cavard \& Lazdunski (1979) for colicin made by strain 20-78, now identified as a colicin of type A. The (incomplete) resistance of $b t u B$ mutants of $E$. coli $\mathrm{K} 12$ lines to colicin A and the blocking of its action by the vitamin both suggest that this colicin adsorbs to a site which at least overlaps the site of adsorption of vitamin B12. However, the sensitivity to colicin A of E-resistant mutants of $E$. coli strains other than K12 (Kadner et al., 1979) and evidence for adsorption of colicin A by outer membrane protein Ia, specified by gene ompF (J. Foulds, personal communication), argue against assignment of colicin $\mathrm{A}$ to the $\mathrm{E}$ group. Colicin $\mathrm{A}$ has heretofore been defined by its inactivity on various classes of resistant and tolerant mutant and by the physicochemical properties of the colicin itself. Our transfer, by DNA transformation, of A-colicinogeny from strain 23 to an A-sensitive K12 recipient enabled us to detect the immunity to colicin A-23 of transformants producing this colicin. The other two A colicins tested, made by the 'type' strain CA31 and by Citrobacter strain 20-78, were also inactive on the K12(ColA-23) transformants, which thus define a colicin A immunity group. Colicin A was active on all our E-immune indicators, and colicins E1 to E7 were active on the K12(ColA-23) strains. Thus, if colicin A were to be considered a member of group E, it would define an immunity subgroup distinct from subgroups E1 to E7.

The immunity to its own type of colicin $\mathrm{E}$ shown by our E-colicinogenic btuB $B^{+}$ transconjugants and transformants was, as in other systems, incomplete, and least nearly complete in the case of E5. However, homologous immunity was such that it was easy to assign $\mathrm{E}$ colicins to their types by this criterion, using the soft-agar layer method. A colicinogenic strain inactive on a $b t u B$ indicator but active on all singly E-immune indicators may produce an E colicin of a type other than E1 to E7, or may produce more than one type of $\mathrm{E}$ colicin. The distinction should be easy if the strain is, or can be made, $\mathrm{BtuB}^{+}$, so that its immunity properties can be tested, or if it can be used as a conjugational donor. However, the identification of the E colicin(s) made by strain P33, as E1 and E4, was achieved only by tests of transformants made colicinogenic by treatment with plasmid DNA from strain P33. No cross-immunity between E colicins was observed in our experiments, though Inselburg (1974) reported some cross-immunity for colicins E2 and E3. An unexpected observation, whose significance remains to be discovered, was that the cloacin plasmid CloDF13 confers immunity to colicin E6. As the cloacin immunity protein has been isolated, it may be possible to test whether it binds to purified colicin E6, when this is available. Escherichia coli $\mathrm{K} 12$ transconjugants carrying ColE4, ColE5 or ColE6 plasmids were more sensitive to colicins E2 and E7 than isogenic non-colicinogenic strains, as shown by increased titres of these two colicins on such strains as indicator, and by the development of zones of partial translucency outside the usual colicin zones (Fig. 2). We have no explanation to offer for the increased sensitivity to colicins E2 and E7 caused by ColE4, ColE5 and ColE6 plasmids (nor for the apparent ability of a second plasmid, of type ColE2 or ColE1 imm or ColE7imm, to reverse such increased sensitivity).

As has been observed for other colicinogenic strains able to adsorb their own colicin, our 
$\mathrm{K} 12 \mathrm{btuB}^{+}$E-colicinogenic transconjugants behaved in the soft-agar layer method as weak producers, presumably because non-induced cells in the macrocolony adsorb most of the colicin released by spontaneously induced cells therein. We think that the phenomenon of capping (i.e. growth of colicin-sensitive indicator cells immediately over, but not around, the killed macrocolony) can be attributed to such adsorption. The absence of capping when the colicinogenic strain was made $b t u B$ or when vitamin B $12(10 \mu \mathrm{M})$ was present during growth of the macrocolony are as expected on this hypothesis; the presence of the vitamin would prevent or reduce colicin adsorption both by repressing production of the $b t u B$ gene product (Kadner, 1978; Kadner et al., 1979) and by competing with colicin for such adsorption sites as were produced. It may seem paradoxical that the concentration of colicin in the soft-agar immediately above a colicinogenic colony should be less than that in the soft-agar a millimetre or so lateral to the edge of the macrocolony. However, we argue that colicin molecules released by induced bacteria located anywhere except at the edge or lower surface of the macrocolony will have a very high probability of being adsorbed by adjacent bacteria and so will not be available to diffuse into the soft-agar layer when this is added, but that many colicin molecules released by bacteria at the edge or lower surface of the colony will diffuse into the bottom agar and so be available for diffusion into the soft-agar indicator layer. Capping has been observed with strains producing colicins other than those of group $\mathrm{E}$ and themselves apt to adsorb the colicin which they produce (B. A. D. Stocker, unpublished; P. Fredericq, personal communication).

The lobate-edge appearance (partly confluent lobes of colicin clearing) suggests that colicin is present at high concentration only at some points in or over macrocolonies of $b t u B^{+}$strains making various E colicins, in particular E5 or E7. As each lobe was much bigger than the 'lacuna' caused by the colicin made by a single induced bacterium (Ozeki et al., 1959), we infer that each lobe corresponds to a component of the macrocolony population, perhaps a subclone, differing from the rest by greater production of colicin (or, less probably, by lower colicin-adsorbing capacity). The possibility that most of the population concerned have lost the colicinogenic property was disproved by tests on single-colony re-isolates. Frequent spontaneous alternation between metastable heritable states, of high probability and of low probability of spontaneous induction of colicin production, might account for our observations. Such alternation might, perhaps, also explain the observations of Inselburg (1979) on a constructed colicin E1 plasmid not conferring immunity to colicin E1: E. coli strains carrying this plasmid produced colonies with depressed sectors, found to correspond to sites of release of most of the colicin produced by the colony. Our few observations on unstable variation in the apparent degree of colicin production amongst single-colony isolates of some E-colicinogenic transconjugant strains are compatible with this hypothesis, though not sufficient to establish it.

Plasmid DNA of colicin factors representing types E1 to E7 has been isolated by Dr A. Pugsley, of Biozentrum, University of Basel, Switzerland (personal communication) and used to prepare E-colicinogenic transformants from an E. coli $\mathrm{K} 12 \mathrm{btu} B^{+}$line, W3110 Nal-r. These E-colicinogenic transformants, because they are isogenic and because each carries only a single plasmid, may be more convenient as standard producers and immune indicators than the strains we used (listed in Table 1). The set of transformants has been deposited in the Plasmid Reference Center (Dr E. Lederberg, Curator), in the Department of Medical Microbiology, Stanford, California 94305, U.S.A.

We thank Drs V. Horak, P. Fredericq, M. Lyman, P. Reeves, A. Chang, J. Foulds, J. Inselburg, B. Oudega, D. Cavard, C. J. Lazdunski, A. Pugsley and E. Veltkamp for the provision of strains, sera and/or unpublished information. This work was supported by Public Health Service Research Grant AI07168, awarded by the National Institute of Allergy and Infectious Diseases. This report is based on the Ph.D. dissertation of Bonnie M. Males. 


\section{REFERENCES}

Aвbott, J. D. \& Shannon, R. (1958). A method for typing Shigella sonnei, using colicine production as a marker. Journal of Clinical Pathology 11, 71-77.

Barry, G. T., Everhart, D. L. \& Graham, M. (1963). Colicin A. Nature, London 198, 211-213.

Cavard, D. \& Lazdunski, C. J. (1979). Purification and molecular properties of a new colicin. European Journal of Biochemistry 96, 519-524.

Davies, J. K. \& Reeves, P. (1975). Genetics of resistance to colicins in Escherichia coli K-12: cross-resistance among colicins of group A. Journal of Bacteriology 123, 102-117.

DiMasi, D. R., White, J. C., Schnaitman, C. A. \& Bradbeer, C. (1973). Transport of vitamin B12 in Escherichia coli: common receptor sites for vitamin B 12 and the E colicins on the outer-membrane of the cell envelope. Journal of Bacteriology 115, 506-513.

FredericQ, P. (1949). Sur la résistance croisée entre colicine $\mathrm{E}$ et bacteriophage II. Comptes rendus des séances de la Société de Biologie et de ses Filiales 143, 1011-1013.

FredericQ, P. (1956). Résistance et immunité aux colicines. Comptes rendus des séances de la Société de Biologie et de ses Filiales 150, 15141517.

FredericQ, P. (1965). A note on the classification of colicins. Zentralblatt für Bakteriologie, Parasitenkunde, Infektionskrankheiten und Hygiene (Abteilung I, Originale A) 196. 140-142.

Graham, A. G. (1974). Ph.D. thesis, Stanford University, U.S.A.

Hamon, Y. \& Peron, Y. (1964). Description de sept nouveaux types de colicines. Etat actuel de la classification de ces antibiotiques. Annales de l'Institut Pasteur 107, 44-54.

Hill, C. \& Holland, I. B. (1967). Genetic basis of colicin E susceptibility in Escherichia coli. I. Refractory mutants. Journal of Bacteriology 94, 677-686.

HoRAK, V. (1975). Typing of Shigella sonnei colicins by means of specific indicators. Zentralblatt für Bakteriologie, Parasitenkunde, Infektionskrankheiten und Hygiene (Abteilung I, Originale A) 233, 58-63.

INSELBURG, J. (1974). Incompatibility exhibited by colicin plasmids E1, E2 and E3 in Escherichia coli. Journal of Bacteriology 119, 478-483.

INSELBURG, J. (1979). Studies of colicin induction with an $\mathrm{imm}^{-} \mathrm{col}^{+}$mutant of the plasmid colicin E1. Molecular and General Genetics 173, 333-338.

KADNER, R. J. (1978). Repression of synthesis of the vitamin B12 receptor in Escherichia coli. Journal of Bacteriology 136, 1050-1057.

Kadner, R. J., Bassford, P. J., JR \& Pugsley, A. P. (1979). Colicin receptors and the mechanisms of colicin uptake. Zentralblatt für Bakteriologie, Parasitenkunde, Infektionskrankheiten und Hygiene (Abteilung I, Originale A) 244, 90-104.

Kirschbaum, J. B. \& KonRAD, E. B. (1973). Isolation of a specialized lambda transducing phage carrying the beta subunit gene for Escherichia coli ribonucleic acid polymerase. Journal of Bacteriology 116, 517-526.

Kool, A. J., Pols, C. \& NiJkamp, H. J. J. (1975). Bacteriocinogenic CloDF 13 minicells of Escherichia coli synthesize a protein that accounts for immunity to bacteriocin Clo DF13: purification and characterization of the immunity protein. Antimicrobial Agents and Chemotherapy 8, 67-75.

Lewis, M. J. \& Stocker, B. A. D. (1965). Properties of some group E colicine factors. Zentralblatt für Bakteriologie, Parasitenkunde, Infektionskrankheiten und Hygiene (Abteilung I, Originale A) 196, 173-183.

Males, B. M. \& Stocker, B. A. D. (1980). Escherichia coli $\mathrm{K} 317$, formerly used to define colicin group E2, produces colicin E7, is immune to colicin E2, and carries a bacteriophage-restricting conjugative plasmid. Journal of Bacteriology 144, 524-531.

Ozeki, H., Stocker, B. A. D. \& De Margerie, H. (1959). Production of colicine by single bacteria. Nature, London 184, 337-339.

Ozekı, H., Stocker, B. A. D. \& Smith, S. M. (1962). Transmission of colicinogeny between strains of Salmonella typhimurium grown together. Journal of General Microbiology 28, 671-687.

Van Vught, A. M. J. J. \& Delamarre, E. C. M. (1977). Genetics of colicin E susceptibility in Citrobacter freundii. Antonie van Leeuwenhoek 47, $7-18$.

Vostı, K. L. (1968). Production and sensitivity to colicins among serologically classified strains of Escherichia coli. Journal of Bacteriology 96, 19471952. 